\title{
Effect of NMDA on proliferation and apoptosis in hippocampal neural stem cells treated with MK-801
}

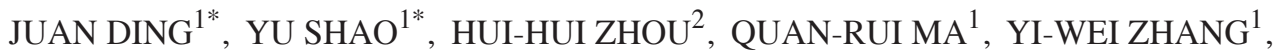 \\ YIN-XIU DING ${ }^{1}$, YU-QING HE ${ }^{1}$ and JUAN LIU ${ }^{1}$
}

\begin{abstract}
${ }^{1}$ Ningxia Key Laboratory of Cerebrocranial Diseases, Department of Anatomy, Histology and Embryology, School of Basic Medical Sciences, Institute of Basic Medical Sciences, Ningxia Medical University, Yinchuan, Ningxia 750004;

${ }^{2}$ Department of Ultrasound, Xijing Hospital, Fourth Military Medical University, Xi'an, Shaanxi 710032, P.R. China
\end{abstract}

Received October 22, 2017; Accepted May 11, 2018

DOI: $10.3892 /$ etm.2018.6346

\begin{abstract}
The purpose of the present study was to investigate effects of $N$-methyl-D-aspartate (NMDA) on proliferation and apoptosis of hippocampal neural stem cells (NSCs) treated with dizocilpine (MK-801). Cultures of hippocampal NSCs were randomly divided into four groups consisting of an untreated control, cells treated with MK-801, NMDA and a combination of MK801 and NMDA $(\mathrm{M}+\mathrm{N})$. Proliferative and apoptotic responses for each of the experimental groups were determined by MTS and flow cytometry. The results revealed that MK-801 and NMDA exerted significant effects on hippocampal NSCs proliferation. Cell survival rates decreased in MK-801, NMDA and $\mathrm{M}+\mathrm{N}$ treated groups compared with the control group. Cells survival rates in $\mathrm{NMDA}$ and $\mathrm{M}+\mathrm{N}$ treated groups increased compared with the MK-801 treated group. MK-801 and NMDA were demonstrated to significantly affect apoptosis in hippocampal NSCs. Total and early stages of apoptosis in MK-801 and NMDA groups significantly increased compared with the control group. Total and early apoptosis of NSCs in the $\mathrm{M}+\mathrm{N}$ group significantly decreased compared with MK-801 and NMDA groups. Late apoptosis of NSCs in MK-801 and NMDA groups significantly decreased compared with the control group. Late apoptosis of NSCs in the $\mathrm{M}+\mathrm{N}$ group significantly increased compared with MK-801 and NMDA groups. The present study revealed that MK-801 inhibited proliferation and increased apoptosis in hippocampal NSCs.
\end{abstract}

Correspondence to: Professor Juan Liu, Ningxia Key Laboratory of Cerebrocranial Diseases, Department of Anatomy, Histology and Embryology, School of Basic Medical Sciences, Institute of Basic Medical Sciences, Ningxia Medical University, 1160 Shengli Street, Yinchuan, Ningxia 750004, P.R. China

E-mail: ryuken0518@163.com

*Contributed equally

Key words: schizophrenia, hippocampal neural stem cells, dizocilpine, $N$-methyl-D-aspartate
NMDA may reduce the neurotoxicity induced by MK-801, which may be associated with its activity towards NMDA receptors and may describe a novel therapeutic target for the treatment of schizophrenia.

\section{Introduction}

Schizophrenia is a severe mental disorder, which affects $\sim 1 \%$ of the world's population (1). Approximately $70 \%$ of schizophrenia cases are inheritable and the condition has a major impact on the quality of life (2). Currently, the pathogenesis of schizophrenia remains unclear (2). Glutamate is an excitatory neurotransmitter, which interacts with the $N$-methyl-D-aspartate receptor (NMDAR), a subtype of glutamate receptors. NMDAR is associated with learning, memory, cognition and synaptic plasticity $(3,4)$. NMDAR subunit 1 (NR1) is a major functional subunit of the NMDAR family (5). NMDAR is regarded as a major contributing factor in the development of schizophrenia (6) and is associated with specific symptoms induced by changes in the glutamatergic system (7).

Several studies have reported that non-competitive NMDAR antagonists, including dizocilpine (MK-801), phencyclidine and ketamine, impair spatial-delayed alternation performance and produce similar behavioral responses in psychosis $(6,8,9)$. Animal models with psychosis have been established based on these agents (10). Furthermore, studies have demonstrated that NMDAR is dysfunctional in schizophrenia, particularly in the hippocampus $(11,12)$. It is well-known that the hippocampus is the region of the brain associated with emotions, learning and memory and synaptic plasticity, which suggests that NMDARs, specifically a dysregulation or hypofunction of NMDARs, may serve a key role in the pathogenic process of schizophrenia (4). Previous studies have indicated that adult neurogenesis is presented within the hippocampus $(13,14)$. However, studies are yet to determine associations between NMDARs and hippocampal neural stem cell (NSC) proliferation and apoptosis.

In a previous study, NMDAR antagonist MK-801 was evaluated to establish a schizophrenia-like mouse model, which produced behavioral responses that closely resembled those observed in hippocampal neurogenesis (14-16). Other studies 
focused on MK-801 to establish schizophrenia-like symptoms and models of behavior $(6,17)$.

In the present study, MK-801 was employed to establish a cell model of schizophrenia, which was used to investigate effects of NMDA on proliferation and apoptosis of hippocampal NSCs. To confirm an association between NMDARs and hippocampal NSCs proliferation and apoptosis induced by MK-801, the mechanism of NMDAR in the pathogenesis of schizophrenia and regulation of hippocampal NSCs was evaluated. Overall, the present study contributed to a better understanding of the mechanisms of schizophrenia and provided an experimental basis for further research in this area.

\section{Materials and methods}

Materials. Dulbecco's modified Eagle's medium (DMEM)/nutrient mixture F-12 (F12), StemPro ${ }^{\circledR}$ Accutase $^{\circledR}$ Cell Dissociation reagent, fetal bovine serum (FBS) and B27 were purchased from Life Technologies (Thermo Fisher Scientific, Inc., Waltham, MA, USA). Epidermal growth factor (EGF) and basic fibroblast growth factor (bFGF) were purchased from PeproTech, Inc. (Rocky Hill, NJ, USA). Anti-nestin antibody (cat. no. N5413), poly-L-lysine hydrobromide (PLL), MK-801 and NMDA were obtained from Sigma-Aldrich (Merck KGaA, Darmstadt, Germany). CellTiter $96{ }^{\circledR}$ Aqueous One Solution Cell Proliferation assay (MTS) was purchased from Promega Corporation (Madison, WI, USA). Annexin V-fluorescein isothiocyanate (FITC) apoptosis assay kit was purchased from BestBio Company (Shanghai, China).

Animals. A total of 50 neonatal C57/BL mice pups $<24$ h old (weight, $1.2 \mathrm{~g}$ ) were provided by the Experimental Animal Centre of Ningxia Medical University (Yinchuan, China). The male:female ratio was $1: 1$. Animals were housed in an animal room (temperature, $22-26^{\circ} \mathrm{C}$; relative humidity, 40-60\%) with a $12 \mathrm{~h}$ light/dark cycle. Maternal animals were individually housed in cages and had free access to standard laboratory chow and water. The newborn offspring were used for the present study within $24 \mathrm{~h}$ of birth. The mice were provided by the Experimental Animal Center of Ningxia Medical University (Yinchuan, China). All protocols were preapproved by the Ethics Committee of Ningxia Medical University (2014-014).

Primary culture of NSCs. The bodies of newborn C57/BL mice were disinfected with $75 \%$ ethanol. Mice were decapitated to obtain the brain tissue, which was kept on ice. Hippocampal tissues were dissected under an anatomic microscope and washed in cold Dulbecco's PBS (D-PBS). Accutase treatment was combined with mechanical separation to digest the hippocampal tissues and the isolated cells were suspended in DMEM/F12, then centrifuged at $200 \mathrm{x} g$ at room temperature (RT) for $5 \mathrm{~min}$ and the supernatant was discarded. The cell suspension was collected following passing through a 400-mesh sieve and seeded in culture bottles $\left(25 \mathrm{~cm}^{3}\right)$. The conditional culture medium was composed of DMEM/F12 (1:1), B27 (2\%), bFGF (20 ng/ml), EGF (20 ng/ml) and penicillin-streptomycin $(100 \mathrm{U} / \mathrm{ml})$. The density of cells was $0.5-1.0 \times 10^{6} / \mathrm{ml}$. The original volume of conditioned medium was $4 \mathrm{ml}$ following culturing at $37^{\circ} \mathrm{C}$ in an atmosphere of $5 \% \mathrm{CO}_{2}$ for $3-4$ days an additional $1 \mathrm{ml}$ conditioned medium was added to the culture bottle. At 5-7 days post-culture the diameter of the neurospheres were $\sim 100 \mu \mathrm{m}$ and subculturing was performed. NSCs were digested by accutase for $\sim 5 \mathrm{~min}$. The NSC suspension was collected and centrifuged at $200 \mathrm{x}$ g at RT for $5 \mathrm{~min}$. The supernatant was discarded and the cells were resuspended in conditional culture medium. The cellular density was $0.5-1.0 \times 10^{6} / \mathrm{ml}$ in a culture bottle. The cells were incubated in an incubator containing $5 \% \mathrm{CO}_{2}$ at $37^{\circ} \mathrm{C}$.

Identification of NSCs. Immunofluorescence staining of nestin (a maker of NSCs) was performed to confirm the successful culture of NSCs. In brief, $0.01 \%$ PLL was coated on the sterile cover slips in 24 -well plates for $30 \mathrm{~min}$. Then the 24 -well plates were washed three times with PBS. On day 4, the 2 nd generation of NSCs were seeded at a density of $1.0 \times 10^{5} / \mathrm{ml}$ in the 24-well plates coated with PLL for $24 \mathrm{~h}$ in an incubator containing $5 \% \mathrm{CO}_{2}$ at $37^{\circ} \mathrm{C}$. The NSCs were washed with $0.01 \mathrm{M}$ PBS and fixed with $4 \%$ paraformaldehyde for $30 \mathrm{~min}$ at RT, rinsed with $0.01 \mathrm{M}$ PBS and incubated with $10 \% \mathrm{BSA}$ for $1 \mathrm{~h}$ at $37^{\circ} \mathrm{C}$. The cells were incubated overnight at $4^{\circ} \mathrm{C}$ with the primary antibodies against nestin (1:200). In the control group, the primary antibodies were substituted with $0.01 \mathrm{M}$ PBS. The glass plates were subsequently washed with 0.01 M PBS three times and incubated with the FITC-labeled goat anti-rabbit IgG (H+L) (1:200; cat. no. A0562; Beyotime Institute of Biotechnology, Haimen, China) secondary antibodies at RT for $2 \mathrm{~h}$. Then slides were washed three times with $0.01 \mathrm{M}$ PBS. DAPI was used to counterstain the nuclei at room temperature for $10 \mathrm{~min}$ and then washed three times with $0.01 \mathrm{M}$ PBS. Images were acquired using an Olympus FV1000 confocal microscope. The positive cells were quantified using Image-Pro Plus 6.0 software (Media Cybernetics, Inc., Rockville, MD, USA).

Preparation of MK-801 and NMDA. MK-801 was dissolved in $\mathrm{DMEM} / \mathrm{F} 12$ at a concentration of $5 \mathrm{mM}$ and stored at $-20^{\circ} \mathrm{C}$. Aliquots were further diluted in DMEM/F12 to a final concentration of 50,100, 200, 400 and $800 \mu \mathrm{M}$ in wells. NMDA was dissolved in DMEM/F12 at a concentration of $50 \mathrm{mM}$ and stored at $-20^{\circ} \mathrm{C}$. Aliquots were further diluted in DMEM/F12 to a concentration of $5 \mathrm{mM}$ and then to a final concentration of 50, 100, 200, 400 and $800 \mu \mathrm{M}$ in wells.

MTS assay. To assess effects of MK-801 and NMDA on hippocampal NSCs proliferation, four experimental groups were defined: Control group; MK-801 (M) group, with cells treated with $200 \mu \mathrm{M}$ MK-801 for $24 \mathrm{~h}$ in an incubator at $37^{\circ} \mathrm{C}$; NMDA (N) group, with cells treated with $100 \mu \mathrm{M}$ NMDA for $2 \mathrm{~h}$ in an incubator at $37^{\circ} \mathrm{C} ; \mathrm{M}+\mathrm{N}$ group, with cells treated with $200 \mu \mathrm{M}$ MK-801 for $24 \mathrm{~h}$ prior to adding $100 \mu \mathrm{M}$ NMDA for $2 \mathrm{~h}$ in an incubator at $37^{\circ} \mathrm{C}$. The 96 -well plates contained $1.0 \times 10^{4}$ cells per well and the NSCs were incubated in an incubator containing $5 \% \mathrm{CO}_{2}$ at $37^{\circ} \mathrm{C}$. Following the above treatment, $20 \mu \mathrm{l}$ of MTS was pipetted into each well of the 96-well plate containing cells in $100 \mu \mathrm{l}$ culture medium. Plates were incubated at $37^{\circ} \mathrm{C}$ for $4 \mathrm{~h}$ in a humidified, $5 \% \mathrm{CO}_{2}$ atmosphere. Absorbance at $490 \mathrm{~nm}$ was recorded using a plate reader.

Flow cytometry. Apoptosis in NSCs was measured by flow cytometry following staining with Annexin V-FITC and 


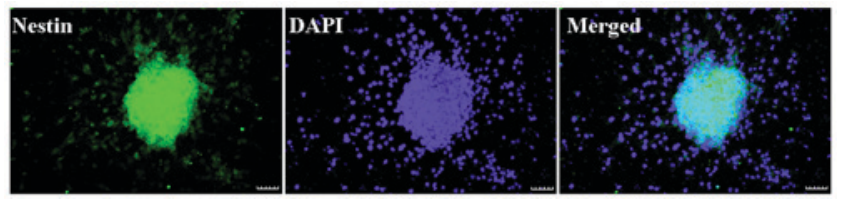

Figure 1. Identification of NSCs. Microscopy images presenting the morphology of neurospheres, with nestin, an NSC or neural progenitor marker in green and DAPI, a cell nuclear counterstaining in blue. Scale bar, $50 \mu \mathrm{m}$. NSC, neural stem cell.

propidium iodide (PI). Cells were treated as described previously and resuspended in binding buffer at $1.0 \times 10^{5} \mathrm{cell} / \mathrm{s} / \mathrm{ml}$. Cell sample solution $(100 \mu \mathrm{l})$ was incubated with FITC-conjugated annexin $\mathrm{V}(5 \mu \mathrm{l})$ and $\mathrm{PI}(5 \mu \mathrm{l})$ for $15 \mathrm{~min}$ at room temperature in the dark. Cells were analyzed by flow cytometry with FlowJo software 7.6.5 (FlowJo LLC, Ashland, OR, USA). Annexin V is a sensitive indicator for detecting early apoptosis in cells. The nucleus of cells in middle and late stages of apoptosis is stained by PI.

Statistical analysis. Data are presented as the mean \pm standard deviation. Statistical significance was calculated by one-way analysis of variance followed by the LSD post hoc test. All experiments were performed in triplicate. $\mathrm{P}<0.05$ was considered to indicate a statistically significant difference.

\section{Results}

Identification of NSCs. Neurosphere with nestin expression (green) and DAPI staining (blue) are presented in Fig. 1. Nestin is an identification marker of NSCs or neural progenitor marker. DAPI is an identification marker for cell nuclei. The merged image demonstrated that nestin (green) and DAPI (blue) were co-localized in the cultured cells. The result indicated that NSCs had a high purity and may be applied in the proposed study.

Concentration dependence of MK-801 and NMDA treatments on NSCs viability. The concentrations of MK- 801 and NMDA were confirmed through the MTS test. MK-801 and NMDA inhibited growth of NSCs in a dose-dependent manner. The research dosage of drugs is always confirmed using the $\mathrm{IC}_{50}$, which is the dosage at which $50 \%$ of the cells die. Typically the dosage of a drug selected for treatment use will cause 50-80\% cell viability. MK-801 at $200 \mu \mathrm{M}$ is $\sim 60 \%$ cell viability (200 $\mu \mathrm{M}$ for $24 \mathrm{~h}$; Fig. 2). Therefore, MK-801 (200 $\mu \mathrm{M}$ for $24 \mathrm{~h}$ ) was used in the present experiments. NMDA at $100 \mu \mathrm{M}$ is $\sim 60 \%$ cell viability (100 $\mu \mathrm{M}$ for $2 \mathrm{~h}$; Fig. 3 ). Therefore NMDA (100 $\mu \mathrm{M}$ for $2 \mathrm{~h}$ ) was selected for use in the present experiments.

MK-801 and NMDA affect hippocampal NSCs proliferation. Compared with the control group, cell survival rates of $\mathrm{M}$, $\mathrm{N}$ and $\mathrm{M}+\mathrm{N}$ groups were significantly decreased $(\mathrm{P}<0.01)$. Compared with the $\mathrm{M}$ group, cell survival rates of $\mathrm{N}$ and $\mathrm{M}+\mathrm{N}$ groups increased significantly ( $\mathrm{P}<0.01 ;$ Fig. 4$)$.

Influence of NMDA and MK-801 treatment on NSCs apoptosis. Total apoptosis rates of NSCs in M and N groups increased

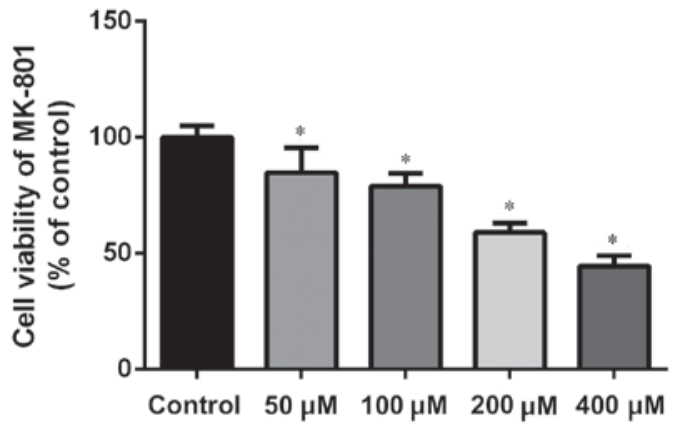

Figure 2. Concentration dependence of MK-801 on cell viability of hippocampal neural stem cells. Cell viability was measured by MTS assay. The final concentration of MK-801 was $200 \mu \mathrm{M}$ for $24 \mathrm{~h}$. Experiments were performed in triplicate. ${ }^{*} \mathrm{P}<0.01$ vs. control. MK-801, dizocilpine.

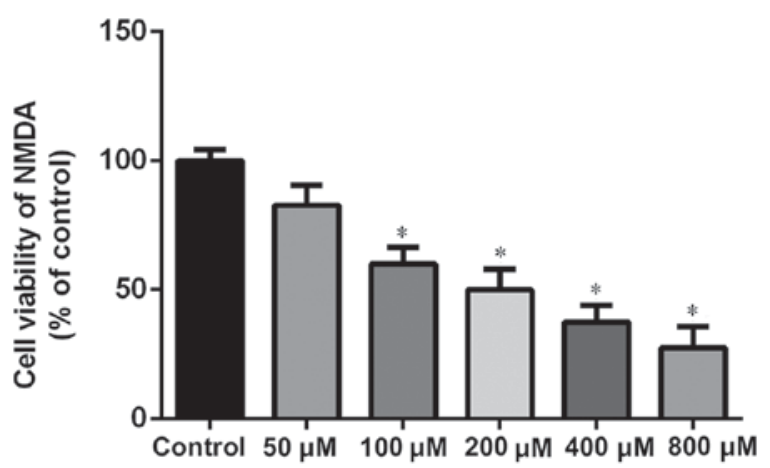

Figure 3. Concentration dependence of NMDA on cell viability of hippocampal neural stem cells. Cell viability was measured by MTS assay. The final concentration of NMDA was $100 \mu \mathrm{M}$ for $2 \mathrm{~h}$. Experiments were performed in triplicate. ${ }^{*} \mathrm{P}<0.01$ vs. control. NMDA, $N$-methyl-D-aspartate.

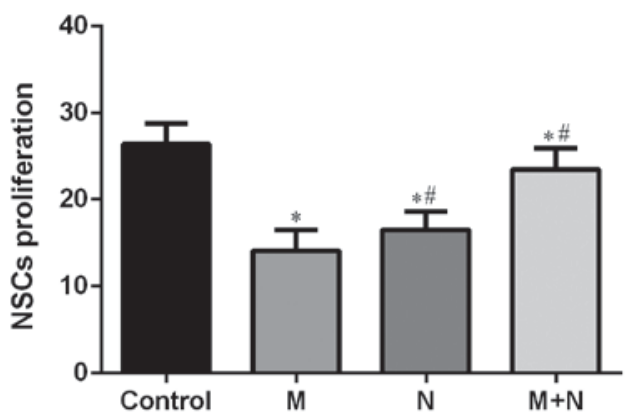

Figure 4. Effects of MK-801 and NMDA treatment on proliferation of hippocampal NSCs. ${ }^{*} \mathrm{P}<0.01$ vs. control; ${ }^{*} \mathrm{P}<0.01$ vs. M. MK-801, dizocilpine; NMDA, $N$-methyl-D-aspartate; NSC, neural stem cell; M, MK-801 $(200 \mu \mathrm{M})$ treatment for $24 \mathrm{~h}$; N, NMDA $(100 \mu \mathrm{M})$ treatment for $2 \mathrm{~h}$; M+N, MK-801 $(200 \mu \mathrm{M})$ treatment for $24 \mathrm{~h}$ followed by NMDA $(100 \mu \mathrm{M})$ treatment for $2 \mathrm{~h}$.

compared with the control group $(\mathrm{P}<0.01)$. Compared with $\mathrm{M}$ or $\mathrm{N}$ group, the total apoptosis rate of the $\mathrm{M}+\mathrm{N}$ group decreased $(\mathrm{P}<0.05)$. No significant difference was observed between the $\mathrm{M}$ and $\mathrm{N}$ groups (Figs. 5 and 6). Early stage apoptotic rates of NSCs in $\mathrm{M}$ and $\mathrm{N}$ groups were revealed to increase compared with the control group $(\mathrm{P}<0.001)$. Compared with $\mathrm{M}$ and $\mathrm{N}$ groups, the early stage apoptotic rate of the $\mathrm{M}+\mathrm{N}$ group decreased $(\mathrm{P}<0.001)$. No significant difference was observed between $\mathrm{M}$ and $\mathrm{N}$ groups (Fig. 7). Late stage apoptotic rates of NSCs in $\mathrm{M}$ and $\mathrm{N}$ groups were significantly reduced 

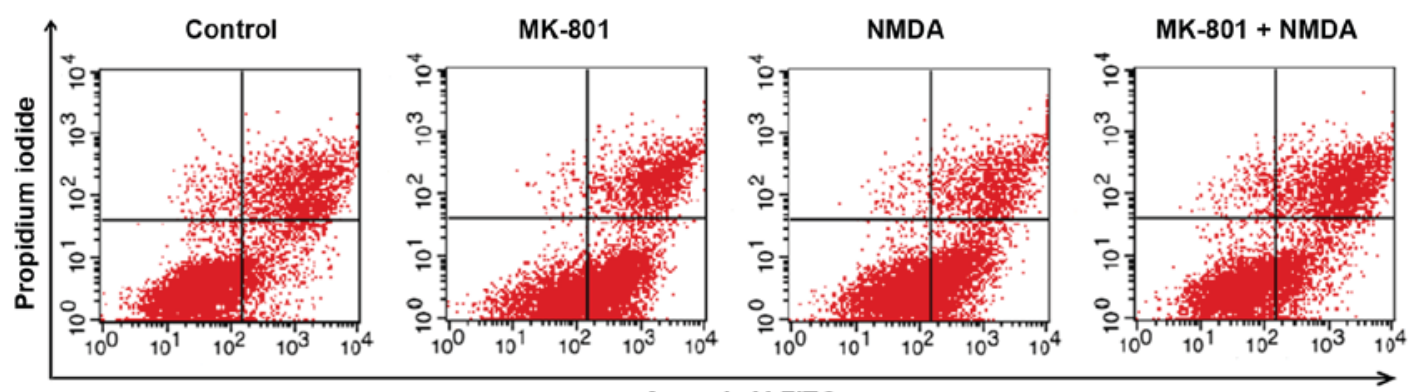

Annexin V-FITC

Figure 5. Effects of MK-801 and NMDA treatment on apoptosis of hippocampal stem cells. Flow cytometry analysis of hippocampal neurospheres for cell survival, necrosis and apoptosis following treatment with MK-801 $(200 \mu \mathrm{M})$ for $24 \mathrm{~h}$, NMDA (100 $\mu \mathrm{M})$ for $2 \mathrm{~h}$ or MK-801 (200 $\mu \mathrm{M})$ for $24 \mathrm{~h}$ followed by NMDA $(100 \mu \mathrm{M})$ for $2 \mathrm{~h}$. MK-801, dizocilpine; NMDA, $N$-methyl-D-aspartate.

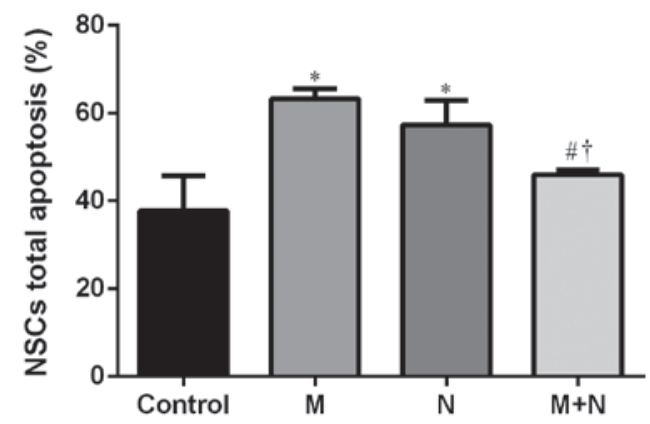

Figure 6. Analysis of MK-801 and NMDA treatment on apoptosis of hippocampal NSCs. " $\mathrm{P}<0.01$ vs. control; ${ }^{*} \mathrm{P}<0.01$ vs. $\mathrm{M}$; ${ }^{\mathrm{P}} \mathrm{P}<0.05$ vs. N. MK- 801 , dizocilpine; NMDA, N-methyl-D-aspartate; NSC, neural stem cell; M, MK-801 $(200 \mu \mathrm{M})$ treatment for $24 \mathrm{~h}$; N, NMDA $(100 \mu \mathrm{M})$ treatment for $2 \mathrm{~h}$; $\mathrm{M}+\mathrm{N}$, MK-801 $(200 \mu \mathrm{M})$ treatment for $24 \mathrm{~h}$ followed by NMDA $(100 \mu \mathrm{M})$ treatment for $2 \mathrm{~h}$.

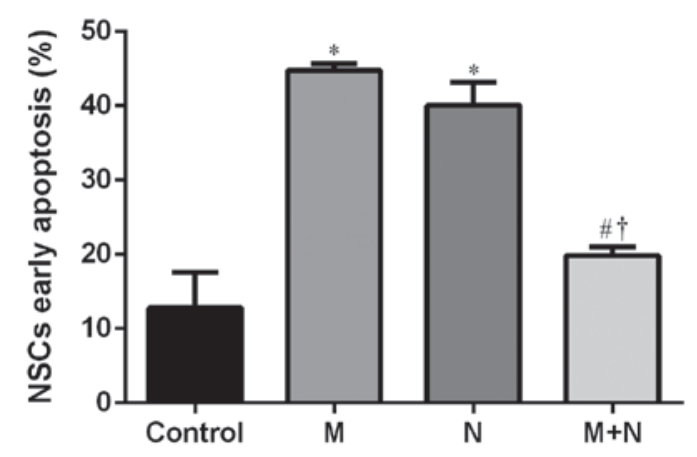

Figure 7. Effects of MK-801 and NMDA treatment on early stage apoptosis of hippocampal NSCs. " $\mathrm{P}<0.001$ vs. control; ${ }^{\text {"P }} \mathrm{P}<0.001$ vs. $\mathrm{M}$; ${ }^{\top} \mathrm{P}<0.001$ vs. N. MK-801, dizocilpine; NMDA, N-methyl-D-aspartate; NSC, neural stem cells; M, MK-801 $(200 \mu \mathrm{M})$ treatment for $24 \mathrm{~h}$; N, NMDA $(100 \mu \mathrm{M})$ treatment for $2 \mathrm{~h} ; \mathrm{M}+\mathrm{N}$, MK-801 $(200 \mu \mathrm{M})$ treatment for $24 \mathrm{~h}$ followed by NMDA $(100 \mu \mathrm{M})$ treatment for $2 \mathrm{~h}$.

compared with the control group $(\mathrm{P}<0.01)$. Compared with the $\mathrm{M}$ and $\mathrm{N}$ groups, the late stage apoptotic rate of the $\mathrm{M}+\mathrm{N}$ group increased $(\mathrm{P}<0.01)$. There was no significant difference between the $\mathrm{M}$ and $\mathrm{N}$ groups (Fig. 8).

\section{Discussion}

Relapse rates of schizophrenia have become a focus of attention as its etiology and pathogenesis remain unclear (2).

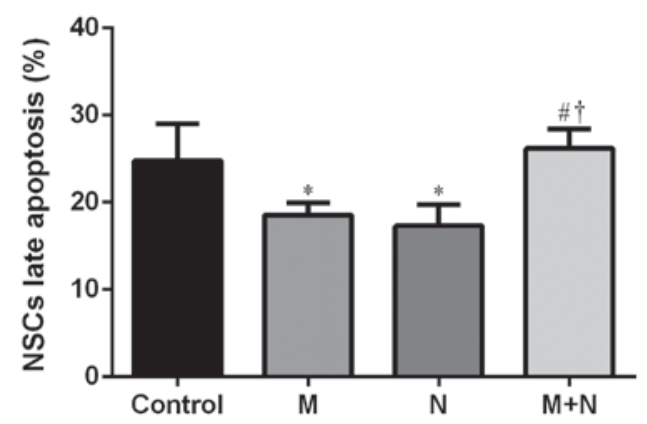

Figure 8. Effects of MK-801 and NMDA treatment on late stage apoptosis of hippocampal NSCs. ${ }^{*} \mathrm{P}<0.01$ vs. control; ${ }^{\#} \mathrm{P}<0.01$ vs. $\mathrm{M} ;{ }^{\dagger} \mathrm{P}<0.05$ vs. N. MK-801, dizocilpine; NMDA, N-methyl-D-aspartate; NSC, neural stem cells; M, MK-801 $(200 \mu \mathrm{M})$ treatment for $24 \mathrm{~h}$; N, NMDA $(100 \mu \mathrm{M})$ treatment for $2 \mathrm{~h} ; \mathrm{M}+\mathrm{N}, \mathrm{MK}-801(200 \mu \mathrm{M})$ treatment for $24 \mathrm{~h}$ followed by NMDA $(100 \mu \mathrm{M})$ treatment for $2 \mathrm{~h}$.

Glutamatergic dysfunction is known to be associated with the pathology of schizophrenia (17). The glutamate receptor hypothesis postulates that schizophrenia occurs in the hippocampus through NMDAR glutamate neurotransmitter system exceptions (5). Glutamic acid caused by glutamate ester is unusual and may result in symptoms of schizophrenia (5). Research has revealed that NMDAR agonists improve symptoms of schizophrenia, indicating that glutamate NMDAR serves an important role in the pathogenesis of schizophrenia (10).

NMDAR is an ionic, excitatory glutamate receptor in the CNS, which is expressed in the hippocampus and cerebral cortex area (18). NMDAR stimulates nerve growth and synaptogenesis and the excited mature receptor promotes learning, memory and other higher order functions (19). Excessive activation of NMDAR causes $\mathrm{Ca}^{2+}$ accumulation in neurons, inducing neurotoxicity and leading to cell death (5). Glycine is an NMDAR agonist, which is used as adjuvant for antipsychotic drugs, combined with traditional antipsychotic medicines, it improves negative symptoms of schizophrenia (20). NMDA and its receptor serve a role in the CNS and affect schizophrenia at least partially mediated by ion channel activity (2). NR1 is a functional subunit of the NMDAR family, which is representative of NMDAR expression levels and is referred to as the core subunit of NMDAR (21). Further studies have revealed that low NR1 expression is associated with low spatial learning and memory function in schizophrenia, 
and the glutamic acid system and other specific regions of the brain expressing NMDAR are closely associated with schizophrenia $(11,22)$. A previous study using a rat model demonstrated that depression following cerebral hemorrhage was caused by enhanced expression of the NMDARs NR1 and NR2B in the hippocampus, accompanied by decreased bromodeoxyuridine expression (23). The results presented in the present study demonstrated that NMDAR antagonist MK-801 and NMDAR agonist NMDA decreased cell viability. NMDARs were significantly inhibited by MK-801 or activated by NMDA and demonstrated neurotoxicity through decreased cell viability. MK-801 inhibited the NMDAR inducing neurotoxicity. Subsequent addition of NMDA activated NMDAR and neutralized the inhibitory effect of MK-801. NMDA may inhibit neurotoxicity induced by MK-801.

Neurogenesis involves proliferation and differentiation of neural precursor cells in the developing and adult brain, which is associated with NMDAR (19). The dysfunction of adult neurogenesis is associated with the etiology of schizophrenia (23). At a cellular level, cell proliferation is a major biological characteristic. The data presented in the present study were obtained using MTS assays and flow cytometry to determine effects of MK-801 and NMDA on proliferation and apoptosis in hippocampal NSCs. MK-801 and NMDA inhibited cell proliferation when compared with the control cells, as using MK-801 or NMDA alone significantly inhibited or activated NMDARs, respectively, leading to neurotoxicity and decreased cell proliferation. Treatment with MK-801, to inhibit NMDARs, followed by treatment with NMDA, to reactivate NMDARs, was demonstrated to neutralize the initial effect of MK-801. NMDA reversed the inhibitory effect of MK-801 on cell proliferation. MK-801 and NMDA demonstrated to induce apoptosis when compared with the control cells. Whereas MK-801 treatment inhibited NMDARs, subsequent treatment with NMDA suppressed stimulatory effects of MK-801 on cell apoptosis. Apoptotic rates of hippocampal NSCs significantly decreased, suggesting that NMDARs may be associated with the process of hippocampal NSC apoptosis and proliferation.

MK-801 inhibits the function of glutamate in hippocampal neurons (24). By blocking $\mathrm{Ca}^{2+}$ channels, it induces neurotoxic effects, which prevent hippocampal neurogenesis and promote apoptosis of hippocampal NSCs $(25,26)$. The NMDAR antagonist ketamine alters neurogenesis by inhibiting proliferation of NSCs (27). In the present study, treatment with MK-801 for $24 \mathrm{~h}$ followed by treatment with NMDA for $2 \mathrm{~h}$ revealed that cell vitality partially recovered and total and early apoptotic levels significantly decreased. The underlying mechanisms may be associated with the activation of NMDAR. NMDA activate NMDAR on hippocampal neurons, change synaptic plasticity and release excitatory neurotransmitters that condition and inhibit MK-801 in a non-competitive role to improve cell vitality $(28,29)$. A further study has revealed that MK- 801 treatment $[0.2 \mathrm{mg} / \mathrm{kg}$, intraperitoneal (IP)] increases NSC proliferation in the hippocampus of a rat model with Parkinson's disease (30). MK-801 treatment results in enhanced hippocampal neurogenesis in the model. Differences between this study and the current study were the dose of MK- 801 treatment $(0.2 \mathrm{mg} / \mathrm{kg}$, IP, rat) compared with $200 \mu \mathrm{M}$ added to the cell supernatant, respectively, and alterations in the model type. Observed effects of MK-801 were therefore different. Effects of low and high dosage of MK-801 varied on proliferation and neurogenesis. Excitatory amino acid toxicity exists in Parkinson's or Alzheimer's disease and MK-801 may be useful in the treatment of these (31). However, effects of MK-801 may be harmful for normal cells. A cell model using MK-801 was established.

In conclusion, on a cellular level, NMDA may inhibit neurotoxic effects of MK-801 on hippocampal NSCs and significantly improve hippocampal NSCs activity and rate of apoptosis, which serves an essential role in proliferation and apoptosis. Limitations of the current study include missing NMDAR knockout or gene silencing experiments. However, MK-801 and NMDA were used to evaluate the association between NMDAR and proliferation and apoptosis of hippocampal NSCs. Exploring regulatory effects of NMDARs on the functioning of the hippocampus and schizophrenia is of importance for an increased understanding of the underlying biology of mental health and it may facilitate identifying novel treatment targets.

\section{Acknowledgements}

Not applicable.

\section{Funding}

The present study was supported by the National Natural Science Foundation of China (grant nos. 81160169, 81460214, 31660270 and 31460255 ) and West China Top Class Discipline Project in Basic Medical Sciences, Ningxia Medical University (grant no. NXYLXK2017B07).

\section{Availability of data and materials}

The datasets used and/or analyzed during the current study are available from the corresponding author on reasonable request.

\section{Authors' contributions}

JD performed the data analyses and drafted the manuscript. YS performed the experiments. HHZ assisted with the experiments. QRM, YWZ, YXD and YQH collected and interpreted the data. JL conceived the study. All authors read and approved the final manuscript.

\section{Ethics approval and consent to participate}

All experimental protocol was approved by the Ethics Committee of Ningxia Medical University (approval no. 2014-014).

\section{Patient consent for publication}

Not applicable.

\section{Competing interests}

The authors declare that they have no competing interests. 


\section{References}

1. Lichtenstein P, Yip BH, Bjork C, Pawitan Y, Cannon TD, Sullivan PF and Hultman CM: Common genetic determinants of schizophrenia and bipolar disorder in Swedish families: A population-based study. Lancet 373: 234-239, 2009.

2. Shorter KR and Miller BH: Epigenetic mechanisms in schizophrenia. Prog Biophys Mol Biol 118: 1-7, 2015.

3. Fouad IA, Sharaf NM, Abdelghany RM and El Sayed NSED Neuromodulatory effect of thymoquinone in attenuating glutamate-mediated neurotoxicity targeting the amyloidogenic and apoptotic pathways. Front Neurol 9: 236, 2018.

4. Dore K, Stein IS, Brock JA, Castillo PE, Zito K and Sjostrom PJ: Unconventional NMDA receptor signaling. J Neurosci 37: 10800-10807, 2017.

5. Ju P and Cui D: The involvement of N-methyl-d-aspartate receptor (NMDAR) subunit NR1 in the pathophysiology of schizophrenia. Acta Biochim Biophys Sin (Shanghai) 48 209-219, 2016.

6. Kim TW, Kang HS, Park JK, Lee SJ, Baek SB and Kim CJ: Voluntary wheel running ameliorates symptoms of MK-801-induced schizophrenia in mice. Mol Med Rep 10: 2924-2930, 2014.

7. Moghaddam B and Javitt D: From revolution to evolution: The glutamate hypothesis of schizophrenia and its implication for treatment. Neuropsychopharmacology 37: 4-15, 2012.

8. Krystal JH, Karper LP, Seibyl JP, Freeman GK, Delaney R, Bremner JD, Heninger GR, Bowers MB Jr and Charney DS Subanesthetic effects of the noncompetitive NMDA antagonist ketamine, in humans. Psychotomimetic, perceptual, cognitive, and neuroendocrine responses. Arch Gen Psychiatry 51: 199-214, 1994

9. Lahti AC, Koffel B, LaPorte D and Tamminga CA: Subanesthetic doses of ketamine stimulate psychosis in schizophrenia. Neuropsychopharmacology 13: 9-19, 1995.

10. Javitt DC and Zukin SR: Recent advances in the phencyclidine model of schizophrenia. Am J Psychiatry 148: 1301-1308, 1991.

11. Duncan GE, Inada K, Koller BH and Moy SS: Increased sensitivity to kainic acid in a genetic model of reduced NMDA receptor function. Brain Res 1307: 166-176, 2010.

12. Harrison PJ, Law AJ and Eastwood SL: Glutamate receptors and transporters in the hippocampus in schizophrenia. Ann N Y Acad Sci 1003: 94-101, 2003.

13. Emsley JG, Mitchell BD, Kempermann G and Macklis JD: Adult neurogenesis and repair of the adult CNS with neural progenitors, precursors, and stem cells. Prog Neurobiol 75: 321-341, 2005.

14. Liu J, Suzuki T, Seki T, Namba T, Tanimura A and Arai H: Effects of repeated phencyclidine administration on adult hippocampal neurogenesis in the rat. Synapse 60: 56-68, 2006.

15. Tanimura A, Liu J, Namba T, Seki T, Matsubara Y, Itoh M, Suzuki T and Arai H: Prenatal phencyclidine exposure alters hippocampal cell proliferation in offspring rats. Synapse 63: 729-736, 2009

16. Yamaguchi M, Suzuki T, Seki T, Namba T, Juan R, Arai H, Hori T and Asada T: Repetitive cocaine administration decreases neurogenesis in adult rat hippocampus. Ann N Y Acad Sci 1025: 351-362, 2004

17. Yu J, Qi D, Xing M, Li R, Jiang K, Peng Y and Cui D: MK-801 induces schizophrenic behaviors through downregulating Wnt signaling pathways in male mice. Brain Res 1385: 281-292, 2011.

18. Bersier MG, Pena $C$ and Rodriguez de Lores Arnaiz G: The expression of NMDA receptor subunits in cerebral cortex and hippocampus is differentially increased by administration of endobain E, a Na+, K+-ATPase inhibitor. Neurochem Res 33 66-72, 2008.
19. Baez MV, Cercato MC and Jerusalinsky DA: NMDA receptor subunits change after synaptic plasticity induction and learning and memory acquisition. Neural Plast 2018: 5093048, 2018.

20. Evins AE, Fitzgerald SM, Wine L, Rosselli R and Goff DC: Placebo-controlled trial of glycine added to clozapine in schizophrenia. Am J Psychiatry 157: 826-828, 2000.

21. Andersson O, Stenqvist A, Attersand A and von Euler G: Nucleotide sequence, genomic organization, and chromosomal localization of genes encoding the human NMDA receptor subunits NR3A and NR3B. Genomics 78: 178-184, 2001.

22. Karlsgodt KH, Robleto K, Trantham-Davidson H, Jairl C, Cannon TD, Lavin A and Jentsch JD: Reduced dysbindin expression mediates N-methyl-D-aspartate receptor hypofunction and impaired working memory performance. Biol Psychiatry 69: 28-34, 2011

23. Taliaz D, Stall N, Dar DE and Zangen A: Knockdown of brain-derived neurotrophic factor in specific brain sites precipitates behaviors associated with depression and reduces neurogenesis. Mol Psychiatry 15: 80-92, 2010.

24. Glushakov AV, Dennis DM,Morey TE, Sumners C, Cucchiara RF, Seubert CN and Martynyuk AE: Specific inhibition of $\mathrm{N}$-methyl-D-aspartate receptor function in rat hippocampal neurons by L-phenylalanine at concentrations observed during phenylketonuria. Mol Psychiatry 7: 359-367, 2002.

25. D'Ascenzo M, Piacentini R, Casalbore P, Budoni M, Pallini R, Azzena GB and Grassi C: Role of L-type Ca2+ channels in neural stem/progenitor cell differentiation. Eur J Neurosci 23: 935-944, 2006.

26. Ambrosio AF, Silva AP, Malva JO, Soares-da-Silva P, Carvalho AP and Carvalho CM: Carbamazepine inhibits L-type $\mathrm{Ca} 2+$ channels in cultured rat hippocampal neurons stimulated with glutamate receptor agonists. Neuropharmacology 38: 1349-1359, 1999

27. Huang H, Liu L, Li B, Zhao PP, Xu CM, Zhu YZ, Zhou CH and Wu YQ: Ketamine interferes with the proliferation and differentiation of neural stem cells in the subventricular zone of neonatal rats. Cell Physiol Biochem 35: 315-325, 2015.

28. Simoes AP, Silva CG, Marques JM, Pochmann D, Porciúncula LO, Ferreira S, Oses JP, Beleza RO, Real JI, Köfalvi A, et al: Glutamate-induced and NMDA receptor-mediated neurodegeneration entails P2Y1 receptor activation. Cell Death Dis 9: 297, 2018.

29. Motin VG and Yasnetsov VV: Effect of NMDA, a specific agonist to NMDA receptor complex, on rat hippocampus. Bull Exp Biol Med 159: 704-707, 2015.

30. Singh S, Mishra A, Srivastava N and Shukla S: MK-801 (Dizocilpine) regulates multiple steps of adult hippocampal neurogenesis and alters psychological symptoms via Wnt/beta-catenin signaling in parkinsonian rats. ACS Chem Neurosci 8: 592-605, 2017.

31. Kysenius K, Brunello CA and Huttunen HJ: Mitochondria and NMDA receptor-dependent toxicity of berberine sensitizes neurons to glutamate and rotenone injury. PLoS One 9: e107129, 2014.

This work is licensed under a Creative Commons Attribution-NonCommercial-NoDerivatives 4.0 International (CC BY-NC-ND 4.0) License. 